\title{
A Relação Entre Texto e Contexto Literário em Filhos da Pátria de João Melo
}

Aline Totoli

\section{Resumo:}

O presente estudo trata da literatura de Angola, a partir da comparação entre as obras Filhos da Pátria, de João Melo, e Luuanda, de José Luandino Vieira, tanto no tocante à parte formal, como à parte de construção da identidade nacional angolana.

Palavras-chave: Colonialismo, Angola, João Melo, José Luandino Vieira. 
Em Breve história da narrativa angolana, Luis Kandjimbo delineia os caminhos percorridos pela literatura angolana desde os primeiros textos romanescos escritos por autores naturais de Angola no fim do século XIX. Essa literatura a qual chamamos angolana passa a se dar como uma literatura de afirmação de uma angolanidade, uma identidade angolana, na poesia, com a geração de 48 , e, na prosa, com a geração de 60.

A literatura passa então a ser o eixo da construção do projeto nacional e traz "para o centro da criação todo um conjunto de temas e procedimentos teóricos que pudessem concretizar o afastamento do colonizador" (KANDJIMBO, 2008). Desse modo, a literatura brasileira serve ao propósito não de preencher o vácuo produzido pelo afastamento da metrópole, mas de funcionar como sua principal interlocutora. Essa literatura em formação "opta por um procedimento antropofágico", novamente em diálogo com a literatura brasileira, articulando em si tanto elementos pertencentes à "tradição" angolana quanto elementos do cânone literário ocidental.

Nessa constituição de uma literatura propriamente angolana, a língua tem papel fundamental: é a partir da subversão do léxico canônico do português, por meio da incorporação de vocábulos das línguas nacionais e pela desestruturação da sintaxe colonial, evidenciando as marcas de oralidade na linguagem literária, que se dá a maior ruptura com o colonialismo.

Em consonância com as rupturas linguísticas provocadas pela mesclagem do universo literário com o universo da oralidade em uma linguagem própria dessa nova nação que se formava, a escolha do musseque como elemento de consolidação e agregação nacional formaliza o projeto nacional.

A geração de 70 se desenha como "um prolongamento natural da anterior", ao passo que a geração de 80 , a geração do período pós-independência, se apresenta buscando "em simultâneo uma (des)continuidade com as gerações anteriores". Essa descontinuidade no universo literário se dá simultaneamente ao estilhaçamento do projeto nacional e à deflagração da guerra civil em Angola e consequente mobilização dos jovens para a guerra. Podemos observar então um novo modo de tentar amarrar essa identidade angolana, que se encontra em profundo descompasso com o projeto anterior. É nessa geração que se enquadra João Melo.

Buscando delinear os elementos estéticos dessa geração e formalizar a relação existente entre texto e contexto literário em Filhos da pátria, farei uma comparação entre este e Luuanda, de José Luandino Vieira, escritor da geração de 60 . 
Quanto ao ponto de vista da narrativa, podemos dizer que na maioria dos contos de Filhos da pátria nos deparamos com uma ruptura com os narradores anteriormente apresentados na literatura angolana, dada por uma demasiada intervenção autoral. Digo intervenção autoral, pois o narrador se designa desde o princípio como narrador-autor. Em Luuanda, lidamos com um narrador onisciente neutro, nos três contos, que apresenta certa simpatia e cumplicidade para com os personagens, chegando por vezes o narrador a tomar como suas as falas dos personagens por meio do discurso indireto livre. Nos contos de João Melo (exceto por "Tio, me dá só cem", "Natasha" e "O feto"), vemos um narrador que se constitui como um autor onisciente intruso, o "narrador-autor", se confundindo por vezes como o próprio autor de tal modo que explica: "É que, como se sabe, a verdadeira distancia entre autor e narrador depende somente do grau e do tipo de dissimulação” .

Esse plano autoral se contrapõe todo o tempo ao plano da narrativa, seja quando expõe algo presente na consciência das personagens, como em "será que esta gaja vai ter com o 'Camarada Excelência'?", ou destila seu desprezo pelas personagens, como o faz ao longo de todo o conto "Efeito estufa", em relação ao estilista Charles Dupret.

Em "Ngola Kiluange" são articulados dois planos de narração: o primeiro, narrado por um narrador-personagem, Antonio Manuel da Silva, e o segundo, pelo próprio narrador-autor, já mencionado. A contraposição dos dois planos é sabida por ambos os narradores, de tal modo que Antonio Manuel da Silva adverte o leitor a respeito das possíveis manipulações e distorções de sua narrativa a serem realizadas pelo narrador-autor .

Em "Natasha", encontramos um narrador-observador que contrapõe relatos de Natasha e Adão acerca da razão pela qual veio ela a acabar em Luanda, por vezes sem a interferência de sua voz apresentando ou mediando os relatos.

Tanto em "Tio, me dá só cem" quanto em "O feto", temos estórias contadas por um narrador-personagem, porém sem a intervenção, ao longo da narrativa, do narrador-autor. Mas esse não é o único aspecto que aproxima tais contos. O primeiro elemento a chamar atenção é a linguagem, que não mais se apresenta com aquela ironia tão áspera presente nos outros contos, mas com um desespero enorme. Os dois contos se mostram gritos roucos por uma ajuda ou uma certa compreensão em uma situação completamente sem saída. Nem ao menos o narrador-autor está presente para com eles dialogar, a interlocução é feita diretamente com o leitor. Não há nada que fazer, somente ouvir.

Diferentemente de Luuanda, em que as narrativas são encenadas principalmente no musseque, os espaços em Filhos da pátria são diversos. A narrativa angolana não só saiu do musseque, para a Avenida Marginal ou para o 
Huambo, mas também saiu de Angola. O espaço narrativo perdeu sua fronteira definida, não sendo mais o musseque, mas sim a identificação com uma identidade angolanas, por vezes óbvia como em "Abel e Caim" ou "Shakespeare ataca de novo", nos quais a ação se dá com angolanos em território angolano ou, como em "Ngola Kiluange", com um despatriado cuja única certeza é a identificação com a cultura e identidade angolana mesmo que a cor de sua pele não permita aos outros relação tão imediata ("angolano, embora branco").

Outro aspecto em que se estabelece a diferença entre as duas obras é quanto à constituição do caráter das personagens. Em princípio, podemos tomar a imagem do mais velho. Enquanto em Luuanda o mais velho é o elemento detentor da "tradição" e da sabedoria e, por isso, respeitado e valorizado na comunidade, em Filhos da pátria o cenário se forma de modo bastante distinto. No primeiro conto, os mais velhos em questão não são os detentores da sabedoria tradicional, mas ex-guerrilheiros que lutaram um dia pela construção do país e agora, por força da adaptação, se tornaram funcionários públicos corruptos. João Melo desarticula essa figura, parte integrante do que considerava Luandino Vieira ser um aspecto fundamental da identidade angolana, seu enraizamento na tradição.

João Melo também desmembra a imagem da criança como símbolo de esperança, do futuro por vir, que todos iriam ajudar a construir, mostrando-a, sem saída, desesperada em um beco esperando pelo leitor, seu único companheiro.

Em Filhos da pátria, podemos observar a construção de um novo projeto nacional, a edificação de uma angolanidade, diferente da defendida em Luuanda por Luandino Vieira, uma identidade baseada em um arranjo não necessariamente harmônico entre a tradição angolana e a modernidade e em oposição ao colonialismo português. João Melo articula uma nova angolanidade, cujo eixo passou a ser a multiculturalidade do angolano e a sua identificação com sua cultura, não mais em oposição ao colonialismo, e, com certeza, não mais a guerra civil.

\section{Referências Bibliográficas:}

CHAVES, Rita. "O projeto literário angolano: a identidade a contrapelo". In: Angola e Moçambique: experiência colonial e territórios literários. São Paulo: Ateliê Editorial, 2005 p.69-75.

LEITE, Ana Mafalda. "Poesia angolana: Percursos (des)contínuos". In: Poesia sempre: Angola e Moçambique, Revista trimestral de poesia, Biblioteca Nacional, no. 23. Rio de Janeiro, 2006, p. 35-50. 
MELO, João. Filhos da pátria. Luanda: Editorial Nzila, $200 \mathrm{I}$.

VIEIRA, José Luandino. Luuanda. São Paulo: Companhia das Letras, 2006.

Artigos da internet:

KANDJIMBO, Luis. Breve história da narrativa angolana. Disponível em: http://www.nexus.ao/kandjimbo/breve_historia.htm. Acessado em 08 de dezembro de 2008, não mais diponível.

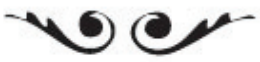

Aline Totoli é graduanda em Letras pela USP.

E-mail: alinemolina@gmail.com 